Copyright (C) 2021 The Author/s

This work is licensed under a CC-BY 3.0 License

Peer review method: Double-Blind

Accepted: August 08, 2021

Published: September 21, 2021

Review article

DOI: https://doi.org/10.47305/JLIA2137280sh

\title{
CHINA-INDIA NEW INTRICACIES: RIVALRY AND COOPERATION IN A NEW CHANGING GLOBAL CONTEXT
}

\author{
Buddhi Prasad Sharma \\ *Leshan Normal University, China \\ ${ }^{* \star}$ Center for Trans-Himalaya Studies (CTHS), Leshan city, Sichuan Province, China \\ ORCID iD: https://orcid.org/0000-0002-2617-7336 \\ yesmanbush@gmail.com
}

\begin{abstract}
At the changing geopolitical landscape with the Covid-19 pandemic scenario, the China-India tussle and scale of regional and global exposition has begun to display with certain consequences, which seems to shake the existing regional balance of power. A mounting political and military confrontation between these two powers as experts suggested could create a hurdle on regional-global stability and can strike on the path of globalization. With historical and existing context analysis, this paper explores that putting genuine differences aside, China and India being responsible stakeholders of the global community, can cooperate and contribute to regional and global peace and prosperity. This paper is based on qualitative research and explorative form in a pattern. This paper concludes that to reduce protracted political and border-related tensions, continuous institutional dialogue, regular communication, and formal-informal exchanges could be effective tools for a peaceful resolution. At this juncture, the competition and cooperation approach could be useful for fostering China-India bilateral relations, and this situation will help to address common challenges of the global community, restructure the global order, and re-adjust regional and global scenarios crippled by the Covid-19 pandemic.
\end{abstract}

Keywords: China; India; Rivalry; Cooperation; International Context; Geopolitics

\section{INTRODUCTION}

With the context of the Covid-19 pandemic effect, the regional and global geopolitical landscape is changing in a new direction. This scenario has created hurdles in the bilateral relations of some countries. The sensitive border issue between China and India particularly since the massive war of 1962 has been a tough issue to resolve and it engrossed international response on many occasions. The two oldest civilization countries China and India have a long history of exchange and cooperation. India was the first non-socialist country to establish diplomatic relations with the People's Republic of China (PRC). At a time when both countries had very few friends in the international forum, the affinity between them sent a positive message to the 
developing world. Since the large-scale war of 1962 to the mid of 1980 relation was worst even though formal and informal communication began from 1970.

Indian Prime Minister Rajiv Gandhi's state visit to China in 1988 helped to create friendly relations, and both sides vowed to promote necessary cooperation by putting differences aside. Certainly, 1962-1988 was a period of mistrust, confrontation, and misunderstanding. Hurdles on political relations hampered economic, trade, cultural, people-to-people contact, and other forms of exchanges. Since the mid of 1970, various forms of formal and informal meetings have happened between officials of both countries, even with foreign minister-level visits. The conducive environment created by the various levels of informal meetings finally culminated with a high-level political visit from both sides. The new rapprochement which began from the end of the 1980s lasted until the 15 June border faceoff of 2020. Between those 20 years, both countries have succeeded to expand multiple levels of cooperation in various areas: trade, investment, exchanges, technology sharing, people-to-people contacts, and many other areas.

The huge scale of bilateral trade, huge investment by Chinese companies in India, large scale of exchanges, and people to people contact exposed that how deep bilateral relation was expanded. But 15 June incident distorted the mode of relations, and again like in the 1960s to the end of 1980, a new type of confrontation has begun, which has amplified tension in the region and also begin to affect global geopolitical equations. Again, it seems that India and China both are feeling a deep threat from one another. According to the study of this paper, the competition and cooperation approach could be a better idea for their bilateral relations. This approach is less destructive and more beneficial. In terms of economy and military, both countries can't ignore each other. At the very distinct global scenario, to reduce the tension and re-harness the cooperation, a new type of understanding and approach is necessary as per the changing regional and global power equation.

At the new regional and global scenario of the post-Covid-19 landscape, China and India with putting their differences aside need to make a common consensus for the sake of the world. The global community is expecting a responsible role of China and India to fight for common pertinent challenges of the world. This paper tries to analyze China and India relations since the 1950s to date and explores real challenges and opportunities on their relations for re-enhancing cooperation and collaboration on the sake of regional and global context. This paper also suggests both countries realize their regional and global responsibility and play a constructive role in the inclusive development of the world. This situation could increase their global stand, recognition, and trust among the global community. 


\section{THE RELATIONS IN A COLD WAR PERIOD}

After WWII, China and India experience new political changes. In 1949, under the leadership of the Communist Party of China (CPC), China became a communist-socialist country, and on the other side, India gained independence in 1947 from British Empire and followed a British-style parliamentary democratic political system. At that time, leaders of China and India were much matured politically due to their long political struggles and experiences. India was the first non-socialist country to establish diplomatic relations with China on 1 April 1950. While many Western countries including the US were not positive about China's new political change, China and India relations from the government to government and political leaders to leaders were strong and cordial. Before the war of 1962, the historical archives showed that there had been a higher level of exchanges, cooperation, and trust-building efforts. Because of the long political experiences of the leaders, it seemed that both wanted to create trust, understanding, and cooperation seriously between political levels and move forward on common issues.

China and India both are ancient civilizations with rich cultural heritage. Before a new political change until the end of WWII, both countries had experienced the bitter humiliation of colonial powers. History shows that in all circumstances bitter or sweat, these two countries never stopped exchanges and cooperation. After 1960 particularly, due to the changing geopolitical scenario of the region, confrontation and competition became the common phenomena in their bilateral relations which obstruct the trustbuilding process.

The Cold War situation had affected their bilateral relations. But most of the experts say that the bilateral political and border issue was a prime reason for deteriorating the relations. From the end of 1950 to 1990, India's foreign policy was not conducted in a proper diplomatic manner. Independent India's first Prime Minister Jawaharlal Nehru was misguided on how to deal with changing regional and international affairs. As a democratic leader, he failed to win the trust of Western democracies, but on another side, he maintained close relations with the USSR and had bitter relations with China. At that time, due to his strong influence on national politics, his party members and opposition leaders did not raise finger against him, but after 1990 many scholars and politicians have been raising issues about many defaults and illdesigned foreign policy of the Nehru era. Even if we read the opinion of Bharatiya Janata Party-related experts, the present deep-rooted domestic structural problems, fragile neighbor policy, and still weak role at international forums are all legacy of Nehru-led India. It seems that in India there is more fear about China, particularly with the rapid rise of China's national socio-economic and military strength. China is a more fraught subject in Indian national debates than India is for China (Malone and Mukherjee 2010). 
The war of 1962 which is said that the Indian PM never imaged India would have suffered a lot was a turning point in India's China policy. After that, as some experts say, India has become more cautious of China even when there were no serious issues to indulge. Due to the growing tension, the historical 'Panchasheela agreement' of 1954 which tells both countries 'Hindi-Chini Bhai Bhai' ('Indian and Chinese are brothers') is no longer working. Distrust and misunderstanding have become two common features of China and India relations after 1962. For normalization of the relations at a time of Cold War, India's Foreign Minister Atal Bihari Vajpayee's China visit of 1979, Chinese Foreign Minister Huang Hue's India visit of 1981, and most importantly Indian Prime Minister Rajiv Gandhi's historical China visit of 1988 paved the way for building understanding and created a new ground for cooperation. The exponential increase in China and India's international economic and diplomatic influence has also augmented the importance of their relations (Ratha 2014).

With large populations, China and India have more things to deal with the internal structural issue. China has eradicated absolute poverty from the end of 2020, which is also recognized by the United Nations (UN), International Monetary Fund (IMF), and World Bank (WB). But for India, the critical poverty issue is a great problem on the social-economic spectrum. Tentatively, the Western world was not much negative with China since the normalization of relations with the US which began in 1971. But on another side, due to India's close relations with the USSR during the Cold war, the Western alliance led by the US had not become relatively supportive of India. Only after the Cold War, the situation became different. With the end of the Cold War, IndiaChina's new phase of rapprochement began, and putting political differences aside, both countries engaged on a multifaceted level of cooperation. The large scale of bilateral trade proves their deeper cooperation and importance to each other even though both countries have many issues to sort out.

\section{THE EFFORTS OF TRUST-BUILDING SINCE 1990}

With the end of the Cold War, the global geopolitical paradigm was shifted into a new direction. In Asia, with economic and military strength, China and India have jumped into the club of great rising powers. Some Indian scholars write that ChinaIndia's new rapprochement which began from the end of the Cold War was just technical, for them cooperation began without trust. For a long time, Indian media has used the term 'China threat' frequently in their coverage (Banyan 2012). Security perspective is a dominant discourse on China-India relations. Even officially they are not using the term 'threat' to each other, it is not hard to tell that their overall relations or cooperation is dominated by the security factor and both don't want to compromise on it in the name of cooperation or partnership. Some experts on the India-China issue 
write that it is futile to use the term 'trust-building' or 'understanding build-up' on bilateral relations of these two countries.

While the communication and cooperation process took the prime role in bilateral relations since 1990, both countries became significant to each other due to their economic and investment-related engagement. Exchange on education and academic sector is also increased. India's trade deficit to China has reached a massive level. Indian companies are saying that due to the high production cost in India in comparison to China, their products can't compete with cheap Chinese products. Sometimes at the requests of Indian companies, the Indian government tries to impose additional tariffs on the products imported from China but due to the vast economic cooperation with China and also international trade rules, Indian actions have been ineffective. In the last two decades, the Indian business community in major cities of China has been increased in a large number. They are engaged in import-export, investment, and other financial activities.

Except for political differences, China and India have many common issues to cooperate with at the global level. Rules of the World Trade Organization (WTO), climate change, many issues raised by the developing world are among the agendas China and India are cooperating for a long time. The group of BRICS (Brazil, Russia, India, China, and South Africa) has become a significant platform to enhance cooperation and the spirit of multilateralism. This platform is taken as an imperative tool to resolve the differences and encourage common agendas based on understanding and trust. China is asking India to sign on bilateral Free Trade Agreement (FTA) to promote trade and financial activities, but India has not decided yet because it is in fear that it could destroy Indian companies and its market for domestic products. Another important regional organization is Shanghai Cooperation Organization (SCO), due to the presence of Russia and Central Asian countries, it supports enhancing regional cooperation and mitigate tensions between countries like China and India.

One understanding within one section of the Indian establishment is that at the economic front, India can take benefits from China's big market opportunity, but in the political sense, coalition building with other major powers like the US, UK, Japan, Australia, and other like-minded countries will be helpful. China seems aware of Indian real interest. After the last June's confrontation, India has been increasing the efforts to engage with other powers to contain China though it is not saying officially. Since 15 June last year, the trust-building process, which began with the end of the cold war, has been declining bitterly. India has reduced imports from China and banned hundreds of Chinese apps. At the present nature of global interconnectedness, both countries can't ignore each other and their comparative advantages only generate from bold engagement rather than fracture relations. 


\section{DIVERSE GEOPOLITICAL INTEREST}

China and India have deeply lack mutual trust even though they are connected heavily in economic and financial spheres. Interest to become a more influential party on a regional and global level is the major aspect of their inherent competition and even sometimes confrontation in relations. Professor David Scott (2008) wrote that these two countries want to rise and constrain others if time favors them using multiple tools like encirclement or building alliances and this kind of 'great game' is displayed on multiple forms like diplomacy, security-military and economic fronts. With the beginning of the $\mathrm{XXI}$ century, a new geopolitical context is evolved in the region. In this very context, two rising powers showed their expanded interest to achieve strategic advantages. Former Foreign Minister of India Yashwant Sinha (2003) once opined that China and India need to understand that both have sufficient strategic space.

Whether in South Asia or the Asia Pacific or even in the Africa region, China and India's geopolitical and geo-economic interest has been enlarged and sometimes even confronting. An "emerging India mean a strong competitor for China from South, West, Southeast and Central Asia to Indian and Pacific Oceans where their interests and influences will clash" says Zhang Guihong (2005). It is said that the 'China Threat' perception on the Indian side is not only of domestic construct, also came from West and Japan both. On 4 May 1998, South China Morning Post reported that India's former defense minister George Ferdinandes said China is a number one security threat for India and it is an even stronger security threat than Pakistan.

China-Pakistan relations have been very cordial for a long time. On another side, India and Pakistan's complexities raised even more than before. Indian leadership feels hard on China's deep friendship with Pakistan. China-Pakistan collaboration based on Belt and Road Initiative spirit seems another complex issue for India. India is blaming that CPEC has violated India's sovereignty and territorial integrity because it crossed through Kashmir territory. China said that there is no intention of violating Indian territorial integrity.

Since the last decade, China and India's geopolitical interest in the maritime sector have been increased at a large pace. This is also another foremost reason why India is showing reluctant to join the Belt and Road Initiative even though China is saying frequently that maritime concern of China is not directed to any neighbor friends. When the Trump administration named Asia-Pacific with another name Indo-Pacific with formulating new Indo-Pacific Strategy (IPS), no doubt what is the real motive of US administration in the region. Trump administration unlike previous administrations had given more space and parameters to India's role in the Indo-Pacific region. Predicting the future intercourse, then senior Chinese official Zhao Nanqi said that China no longer accepts that the Indian Ocean is only of India's ocean (Nanda 2002). India has taken China's 'string of pearls' strategy as a serious threat to its national security, and 
encirclement to it from major points of the Bay of Bengal and the Arabian Sea by China (Mohan 2005). India seems wary about China's growing constructive presence in the rest of South Asian countries. In the last two-decade, China's investment, trade, exchanges, visits, and cooperation on multiple common issues with South Asian countries had been increased at a higher pace.

Even with India, before the June 2020 face-off at the border area, volume and parameter of cooperation with the Chinese were higher. India feels that its border troops are stronger and can defeat Chinese troops in a battle (Yu 2020).

Analysts say that due to India's big brother attitude and interfering approach, it has lost credibility among South Asian friends. Indian policymakers also realized that anti-India sentiment in the rest of South Asian countries has been increased than before, but unfortunately, the Indian side seems not ready to change hegemonic behavior. This outdated and failed neighbor policy of India is also one of the reasons why the rest of South Asian countries except Bhutan are very eager and positive to cooperate with China on both hard and soft power arenas. Understanding India's failure diplomacy in the region, China has increased its efforts to show more generosity, supportive approach, and cooperative form to the rest of its South Asian friends. Even when effected by the pandemic, China has shown the world that it has the power and conviction to move boldly (Agrawal 2020).

Direct large-scale war seems difficult due to the geographical hurdles. Though both sides have increased numbers of troops, a big war would be exceptionally difficult (Griffiths 2020). After the June 2020 face-off, India not only increased military personal, infrastructure building at the border area, and partnership building with many other countries of West and Asia but also taken many steps to resist Chinese influence in India in the areas of technology, finance, trade and many other. If we look at India's Look East Strategy it is not difficult to find real interest behind this strategy. Through this Strategy, India wants to play a new balancing game against China in Southeast Asia and AsiaPacific Region. India's land and maritime security interest are increased on a large scale. Since the last decade, India's increasing strategic relations and cooperation with Vietnam as analysts say is another game of India to counter China from the Asia Pacific region. For both China and India, strategic consolidation in the maritime arena has become an issue of common concern and trend (Mukherjee 2020).

\section{THE NEW BORDER FACE-OFF}

China-India skirmishes of June 2020 have deteriorated the relations into the worst condition. According to the media reports, the small scale of quarrels and tussles since May had culminated into the dreadful accident of 15 and 16 June, where 20 Indian soldiers died, and according to the Chinese side, there were big casualties on their side too (The Hindu 2020). This incident was the largest scale of confrontation between 
troops of the two countries since the clash of 1967 in the Nathu La area where both sides had lost many troops. This incident has not only changed the nature of the ChinaIndia border issue but also the character of military competition between these two countries (Joshi 2020). Due to the long Himalayan border, on many occasions, both sides come together on patrolling and even many times they confront without arms.

For a long time, the Galwan River area had been peaceful even though both sides have their interpretation, but since several years ago it has become a hot spot of military confrontation. India blamed China for the 15 June incident saying that the Chinese side encroached on its territory. China rejected India's blaming and said that their troops were aware of their territory and the Indian side instigated the situation. Since several years ago both countries have built massive infrastructure at the border area. Though as per the scale of the incident, the 15 June face-off was a large scale, small-scale confrontations without using arms have been common at the LAC areas. In that context, ground commanders of both troops talked and settled the dispute peacefully. Until today various levels of talks including foreign and defense ministers level happened between both countries aiming to deescalate the situation and back to the normal condition. But risks of further escalation can't be ignored (Panda 2020). Ladakh area is strategically very important for both countries due to the military purpose. China and Pakistan have already made understanding on their side of the border areas because of their deep friendly relations. In the realist sense, China and India can't trust each other in the security and political sphere.

Indian media were reported that after the clash with the Chinese side, the Indian security establishment has given importance to two strategies: 1) first is to buy and develop sophisticated weapons, and 2) entering into new groups of powerful likeminded countries like the US, UK, Japan, Australia, Canada and so on. Some Indian media say that India-China relations will not be back on the old normal situation. The Indian security agency has taken North Sikkim and East Ladakh areas more sensitive zone and if foreign forces enter into those areas, according to them it would be a direct risk on broad border security management. This is one of the reasons, why the Indian establishment became active in leaving its long Non-Alignment foreign policy and search international supports for security aspects. Indian side telling that Chinese side has hesitated to back from their area which would further escalate the tension in the future (ET Online 2020). India has built a feeder road in the Galwan Valley area which China has strongly objected saying that area belongs to it and India has encroached with rejecting basic agreed norms. Taking the situation strategically difficult, China has increased numbers of border troops in the Galwan Valley border area.

China has taken strategically significance of the Galwan Valley seriously because it is linked with the overall security of the Ladakh region (Reyar 2020). Before that, an informal meeting between Chinese President Xi Jinping and Indian Prime Minister Narendra Modi in Wuhan city of China in 2017 was fruitful to make consensus on 
resolving all issues through dialogue and communication. For the border issue, both leaders agreed to expand the level of communication on reducing tension and maintaining peace and order. China demands India to adhere to the Wuhan spirit and stop unnecessary infrastructure in the Galwan Valley area (Pillay 2020).

Before the war of 1962, China had proposed to India a proposal to resolve the border problem. But then Indian Prime Minister Nehru had not agreed on it. After the war, China ordered its troops to back $20 \mathrm{~km}$ behind the claimed line in Ladakh (Sawhney 2020). When normalization of the relations began in the 1980s, both nations had taken some institutional mechanisms in which these institutions took immediate steps to address the clash promptly. Even after the 15 June incident, various levels of negotiation were held to talk and make calm the border area. Both governments have given rights to these institutions to discuss and find tangible ways to reduce tensions.

\section{MAJOR CHALLENGES ON RELATIONS}

Experts on Sino-Indo relations say that the first and foremost challenge on fostering relations between these two rising neighbors is the lack of trust. Real trust in opinion and behavior is the big issue in their bilateral relations. Even since the normalization of relations after the bitter relations during the Cold War period, the trustbuilding process was very slow even though they started multiple levels of cooperation. Due to this scenario, still, people of both nations have very limited knowledge about new changes. Chinese scholar Cheng Ruisheng (2002) writes, "on the one hand both are making great efforts to resolve these differences through various dialogues and mechanisms; on the other hand, both agree that problems and difference should not become impediments to the development of their friendly relations". Political history since the end of WWII shows that if there are continuous exchanges besides hard power cooperation, the possibility of increasing understanding, positivity, and constructive environment on relations would be very high. Without soft power intercourse and sharing, it will be very hard to win the heart and mind of the other side. One of the reasons why the US administration put the soft power aspect importantly on its global power projection is that soft power can have a long impact on foreign people and support to create a conducive environment even in a tough political situation.

The political relation between India and China to this date says that security concern is the biggest obstacle in their friendly relations. Long boundary dispute has put their relations always on the sensitive sphere which could enter into confrontation scale anytime. Tibetan issue is sensitive for China, and India has been blamed to play the Tibetan card against China. Formally, India has recognized Tibet as an inherent part of the People's Republic of China (PRC). And similarly, China has recognized Sikkim as a part of India. But they have different approaches on the border issue. After the 15 June incident, Modi's government has been taking very tough approaches against China and 
increase domestic and international capabilities to restrain China. It looks that India will join all international alliances which aim to detect the rise of China. This attitude will increase the new level of confrontation in the Asia-pacific region. Until today, both countries have dispatched large scale of troops in a border area even though diplomatic channels continue searching for resolution (Huang 2020). The economic aspect is another issue both are competing and cooperating. Globally, China and India both have many common agendas to fight against trade protectionism and rules favorable for advanced countries like the US, UK, Japan, and so on. But as per their bilateral concern, on one side, their trade volume has been increasing to a new height and on another side particularly due to its large trade deficit with China, India has started many measures to reduce the trade deficit with China. According to Indian media, after the 15 June incident, Modi's government has launched a systematic effort to reduce the huge amount of imports from China. India is harassing Chinese companies and issuing hard rules to restrict Chinese investments and economic collaboration. Banning hundreds of Chinese apps, India showed her tough approach toward China.

India always wants to show that it is the largest democracy in the world. Most Indian scholars try to praise their political system as the best model. India needs to invest a lot in infrastructure which can give national strength to show a strong presence (Barlett 2020). Political and ideological differences between Chinese and Indian systems are critical factors to damage trust and understanding between them. Post-1990 India, though their leaders say that India will not incline to any power nations and maintain strategic autonomy, in reality, happening is different. India purposefully moves to build a block of some like-minded nations which are not positive with China politically and vow to contain China strategically. An increasing strategic partnership between India, the US, Japan, Australia, Canada, and many other nations, without any doubt, tell that they are very systematically moving forward to encircle China from many aspects of the regional and global spheres. Some Indian diplomats say that due to the 15 June incident, Modi's government has decided to take much faster and tough measures to detect China using national and international strength and alliances. Some experts say that this will not support peace and order in the region, but for them, it just increases confrontation and misunderstanding between India and China, and between the major powers at large. China and India have had a deep conflict for a long time which is hindering bilateral relations.

Political, ideological, security, regional influence perspective, neighbor approaches are the major issues they are competing. An Anti-China Western country particularly the US tries to encourage India to take a strict stand to contain China. For the anti-China Western bloc, India is a strategically significant country to create a base and make a collective target against China. This situation might escalate further regional tension and rivalry between China and India. The experts who take a balanced approach on China-India relations are suggesting that India and China should come on tangible 
dialogue and with deep discussion need to find ways of resolution of the problems and challenges. Strong leadership of both countries would have the capacity to settle the issues if they are really serious. Inviting foreign powers in the region cannot provide a peaceful solution. Both countries are raising powers and each country can take huge benefits from each other. So, it will be better to continue the meaningful dialogue and resolve issues step by step respecting one another's sovereignty and status.

\section{EXPECTATION OF GLOBAL COMMUNITY}

The entire global community is observing the rise of India and China with interest. The rest of the world puts sympathy and a cooperative attitude toward India and China because these two countries, having a big population, still need to do a lot to eradicate structural problems. From the end of 2020, China has officially eradicated absolute poverty, which is one of the significant plans of its Two Century Goals. India can learn from China's pragmatic experience on eradication of poverty. Historically, both India and China contributed a lot for peace, stability, knowledge sharing, and harnessing cooperation in the world. 'Vasudhaiva Kutumbakam' ('We all are brothers' or 'the world is one family') concept of India and the 'old Silk Road' concept of China both depict their cooperative and benign approach toward the world since the ancient time.

China being a second economy needs to show a supportive and cooperative approach toward the world. Without the support of the rest of the world, it would be hard for China to achieve such kinds of development within a short period. So now the rest of the world is expecting a responsible, benign, supportive, and cooperative China (Sharma 2019; Sharma and Khatri 2019). They don't want to see China be like the hegemonic nature of Western countries in history. The US, UK, Germany, and many other countries of the West had a very bad history of colonizing, interfering, and trouble creating the internal matters of many other countries of the different continents. For China, just saying that it is a still developing country would not be a satisfactory answer. It must demonstrate supporting conduct in action rather than just in words. With changing the geo-political equation, India will be reluctant to welcome China's investment in significant areas and similarly, it also discourages its homegrown companies from working in China (Min 2020). Experts say that due to China's noninterfering approaches since the establishment of PRC, it still has many things to do to assure the rest of the world that its rise will support the peace and prosperity of the entire global community and no country needs to be afraid from China's development. The rest of the world wants to see China more responsible and significant stakeholder.

Similarly, India also had a long history of peaceful rise. Since ancient times, India was a famous place for knowledge sharing. Before the colonization, India's economy and educational development was highly recognized in the entire world. At now, India's international role and responsibility also increased, and India can't say that being a 
developing country, it won't offer more support to the world. There are hundreds of countries on the planet that are weaker and poorer than India. The rest of the world wants to see a responsible and supportive India. Unfortunately, India's behavior toward its small neighbors has not been positive and it is more interfering. India needs to change this kind of hegemonic behavior and pragmatically follow the cooperative, noninterference, and benign foreign policy. The door is open for India to participate in an important pact and take opportunities for its development (Dai 2020). A hegemonic India toward the neighbors can't be said to be positive to the rest of the world. Now, as per strength, India has come to the position to tell the rest of the world that it is up to the world community to cope with common challenges and find a solution of all global perversion to create a safe and better world.

China and India need not reiterate that we are still developing countries and our focus is on domestic management. Because now they are strong economies and gained strong voices in the regional and global sphere. They have something they can deal with and address about the common problems of the developing world. On many occasions, developed countries have ignored the challenges facing by developing countries. They try to impose their interest toward others and this would not resolve other's problems. But China and India, these two rising powers are now in a condition to strongly lobby, speak and push issues on the front and can fight collectively for the common interest of the developing world. This is the most important responsibility they can contribute to the diverse developing world. Expectation means there is hope for them. If India and China work and fight for the common interest of the developing world, certainly their international recognition, status, and stand will be high and respectable.

\section{THE CONNOTATION OF COOPERATION IN A NEW GLOBAL CONTEXT}

The Covid-19 pandemic has changed a trend of the global landscape. As experts say pandemic has taught human beings a lot that they should foster more cooperation and solidarity to protect the nature and restart to maintain harmony with the nature. Covid-19 has disclosed the real capabilities, management skills, structural problems, and reality of national strength to fight large-scale crises particularly of industrialized nations like the US, and second the developing world. The poor handling of the Covid-19 situation by the US administration shows that it is not a real tiger on the international fronts. The economically and militarily powerful country the US has become the most affected country by the pandemic. If we observe many international polls status, image and attitude toward the US are declined very low and the rest of the world was observing in wonder the poor institutional capabilities of the US to deal with the critical crisis. China and India both are serious on the issue of extremism and terrorism, which is also a critical issue for many countries of the world. Particularly, both the US and the EU have a double standard role to address the challenges created by terrorist groups. Since 
1945, the US is one of the most destructive countries to support terrorist and extremist groups in other countries and create a massive scale of instability, violence, and chaos. This double standard policy also hampers the institutional development of countries of the Asia Pacific region.

Some Indian affairs thinkers try to see positive possibilities in the region citing the history. China "needs to recognize that the last 70 years have been an aberration in a mutually beneficial relationship that goes back nearly 2000 years, with strong economic, religious, and cultural ties based on mutual respect and admiration", says Pillay (2020). But still, there are strong voices among Indian thinkers that India needs to take a more realistic approach to address the China factor. When the gap in national power widens in favor of Beijing, then India needs to think of a new approach because the traditional perception of Delhi on China can't be sustainable (Mohan, 2020). Experts opine that due to China's strength and global connectivity, India can't ignore this reality even in the time of confrontational relationship with China (Chaudhuri 2020).

In the scenario, China and India as they agreed on their bilateral discussions many times to work together to fight against extremist and terrorist groups, could be effective and can support many countries to tackle critical challenges. The second is the trade issue. Due to the protectionism approach of many developed countries, the developing world has been facing severe problems with global trade. For this purpose, China-India cooperation is necessary. The World Affairs (2020) writes, "a smart India will stay friends with the US and, at the same time, leverage China to make peace with Pakistan. That will be the wisest and Nobel prize-deserving ingenuity. Freeze border disputes for a few years and focus on growth, trade, and peace. Don't become a victim of the divide-and-rule playbook". If China and India work together, they will get the support of many other developing countries to create new trade order against protectionism.

Covid-19 scenario and changing geopolitical dimension presently show that China and India have entered into a new era of confrontation and distrust. With accepting differences, experts suggest that for sake of globalization and a liberal economic approach, their interdependence and interconnectedness are beneficial for both countries. The widening gap on a developmental level between these two countries has led to a new phase of confrontation, and India wants to be the leader in the developing world (Hu 2020). China and India are among very few countries that got a large scale of benefits from the spirit of globalization. But with changing new global economic and social context, it seems new thinking and approaches on globalization are required. On one side, developed economies like the US, are promoting protectionism ignoring international trade rules regarding globalization, and on another side, poor economies are experiencing that globalization trend, and international trade rules are not supporting them, because their products and service can't compete on international markets. In this critical scenario, the two biggest developing countries China and India 
jointly can work together and play the bridging role by eradicating the hurdles of hyperglobalization, protectionism and address the genuine problems facing by poor economies.

Climate and environmental issues are other significant common issues in which China and India need to work together with taking support of the developing world. Particularly, developed economies have a double standard policy on the climate issue. The developing world wants more compromise and concrete initiative from developed economies to address climate change. China and India need to cooperate on the climate change issue without any hesitation.

Similarly, their experience of economic development and model of creating a business-friendly environment can be a useful example to the developing world. They can cooperate on investment and joint manufacturing sectors in many countries.

Changing the new global context demands more solidarity and cooperation between major powers of the world. Covid-19 teaches that for a common enemy of humanity, we need to foster combine efforts and use a collective approach to address the challenges. Both countries need to realize that in the context of the present global scenario they are highly expected to play a globally responsible role as significant stakeholders, to contribute to global peace, stability, and prosperity. Putting aside their long differences, these two rising powers can do better to make the world more interconnected, globalized, and safer for a future generation.

\section{CONCLUSION}

After 1950, China and India have experienced both good and bad taste in their bilateral relationship. In the decade of 1950, they had enjoyed 'Hindi-Chini Bhai Bhai' ('Indian and Chinese are brothers'). But after that, both had started to feel misunderstanding, threat, and importantly border issues came in a front of their discussion. This situation culminated with the destructive war of 1962, which took hundreds of lives from both sides. Indian Prime Minister Rajiv Gandhi's historic China visit of 1988 played a vital role to begin a new rapprochement which was derailed since the war of 1962. According to the officials of both sides, to bring the situation of 1988 level there had been long series of many levels of meetings and exchanges.

The consensus of the China-India 1988 understanding was that they can continue cooperation putting the differences aside, and they will put all efforts to resolve all differences through meaningful dialogue, negotiation, and communication. India and China have basic differences on domestic and global issues, which illustrate their bilateral relations on many occasions (Paul 2018). Although China and India are neighbor countries, have broad differences in the political, economic, and social model they adopted. The political difference has led them to make their relations less trustful and more misunderstanding. India has called itself the largest democratic country, and 
on the other side China, after the dissolution of the Soviet Union, has been the largest communist-socialist country on the planet. Based on their political system, the socioeconomic models they adopted are structurally different.

Though these countries are saying that whatever political system they adopted will not affect their bilateral relations and cooperation, in reality, they are still failing to earn trust from one another. Indian thinks that China will never accept India as a rising power in Asia (Kulkarni 2017). The last 15 June incident had further deteriorated relations, and it seems that another level of confrontation began with this incident. Fear in the region increased in the sense that China-India open confrontation could have a long-term effect on peace and stability. Geo-politics need to be driven with deliberate communication with controlling unnecessary tensions (Parker 1998).

As discussed previously, the rise of two large populous countries China and India have raised positive hope among the developing world even though still the rest of the developing countries have not felt practical necessary support from China and India. China and India can't stay separate due to their geographic proximity. History says that geography plays a significant role in bilateral and international relations between countries (Spykman 1944).

In the changing context of the global scenario, China and India need to play a more constructive and responsible role in the regional and global context at large. These two countries at the economic front have achieved massive development and have strong political and administrative institutions to accomplish their respective policies and plan. Chinese leader Deng Xiaoping (1980) proposed a 'peaceful rise' approach while he formally launched reform and opening policy. As experts say China's rapid development and search for a new global order has not given proper sleep to the present superpower America. In this global scenario, to avoid the 'Thucydides trap' China can openly tell to US establishment that it does not have any intention to challenge the US and it wants more in-depth cooperation and partnership with the US. For a post-pandemic peaceful global order, mutual understanding, comprehensive dialogue and mutual trust between the US and China seem essential. Positive US-China rapprochement will have positive communication and cooperation between China and India too.

At the changing geopolitical landscape at the post-Covid-19 pandemic scenario, China and India bilateral relations and their level of regional and global exposition will have a positive and negative impact on the global balance of power. Having recognizing their genuine differences, if these two powers for the sake of global peace and prosperity, cooperate and jointly move forward as responsible stakeholders of the global community, can create hope, constructive environment, and finally, support to detect restrain elements for peace. From various forums, the global community shows the expectation of the tangible supportive role of China and India in the world. As per the present global challenges, China and India can't limit them only in the regional 
sphere, but a significant and responsible role needs to be focused on the global level. Dialogue, communication and continue negotiation will support creating trust and confidence in their relations. Competition and cooperation approach could be useful for China-India relations, and their combined efforts to address common challenges of the global community will support to restructure the global order, and situation particularly crippled by Covid-19 pandemic. 


\section{REFERENCES}

1. Agrawal, Ravi. 2020. "Why India and China are Sparring." Foreign Policy, May 28, retrieved: https://foreignpolicy.com/2020/05/28/why-india-china-sparringborder-clashes-conflict/

2. Banyan. 2012. "India-China Relations and the Media. Blame the Messenger." The Economist, May 21, retrieved: https://www.economist.com/banyan/2012/05/21/blame-the-messenger

3. Bartlett, Duncan. 2020. "Can India Benefits from the World's Frustration with China?" Economic Times, May 27, retrieved:

https://economictimes.indiatimes.com/news/economy/policy/can-india-benefitfrom-the-worlds-frustration-with-

china/articleshow/76029685.cms?utm source $=$ contentofinterest\&utm medium $=\mathrm{t}$ ext\&utm campaign=cppst

4. Batabyal, A. 2006. "Balancing China in Asia. A Realist Assessment of India's Look East Strategy." China Report 42/2, p. 179

5. Chaudhari, Archana. 2020. "India's China Standoff Shows Risks of Getting Too Close to Trump." Bloomberg News, June 5, retrieved:

6. https://www.bloomberg.com/news/features/2020-06-04/india-s-china-standoffshows-risks-of-getting-too-close-to-trump

7. Cheng, Ruisheng. 2002. "China and India: Challenges and Opportunities for the Transformation of Ancient Relations in the Future." China Report, 38:1, Sage Publications, New Delhi

8. Dai, Yonghong. 2020. "New Delhi Cannot Afford to Play Geopolitical Games." December 17, Global Times, retrieved: https://www.globaltimes.cn/content/1210286.shtml

9. Deng, Xiaoping. 1980. The Present Situation and the Tasks Before Us.In Selected Works of Deng Xiaoping, Beijing: Foreign Language Press

10. ET Online.2020. "Galwan: 10 Things to Know About the Latest India-China Battle at 14,000 ft." The Economic Times, June 17, retrieved:

https://economictimes.indiatimes.com/news/defence/galwan-10-things-to-knowabout- the-latest-india-china-battle-at-14000-ft/articleshow/76402649.cms

11. Griffiths, James. 2020. "Why are China and India Fighting over an Inhospitable Strip of the Himalayas?" CNN, June 9, retrieved:

https://edition.cnn.com/2020/06/17/asia/india-china-aksai-chin-himalayas-intlhnk/index.html

12. Huang, Kristin. 2020. "China and India Muscle Up After Border Dispute but Diplomatic Channels Open." South China Morning Post, May 19, retrieved: https://www.scmp.com/news/china/diplomacy/article/3085064/china-and-indiamuscle-after-border-dispute-diplomatic 
13. Hu, Shisheng. 2020. "India Changes Attitude Toward Multilateral Mechanisms for its Global Ambition." Global Times, December 17, retrieved: https://www.globaltimes.cn/content/1210221.shtml

14. Joshi, Yogesh. 2020. "Commentary: China's Boundary Skirmishes with India have Wider Economic and Geopolitical Implication." Channe/NewsAsia, June 19, retrieved: https://www.channelnewsasia.com/news/commentary/china-boundaryborder-skirmishes-india-troops-modi-tibet-lac12849122 ?cid=linkedin traffic social 10082018 cna

15. Kulkarni, Sanjay. 2017. "China Will Never Accept India as a Rising Power in Asia, Cooperation Seen as Cowardice." News 18, July 28, retrieved: https://www.news18.com/news/india/opinion- china-will-never-accept-india-asa-rising-power-in-asia- cooperation-seen-as-cowardice-1476297.html

16. Malone, David M. and Mukherjee, Rohan. 2010. "India and China: Conflict and Cooperation." Survival, Feb-March Issue, Vol. 52, No. 1, Accessed September 16, 2020, doi: 10.1080/00396331003612513

17. Mohan, C. Raja. 2020. "India's Pivot to the United States." EastAsiaForum News, May 19, retrieved: https://www.eastasiaforum.org/2020/05/19/indias-pivot-tothe-united-states/

18. Mohan, C. Raja. 2005. "There's a New Game in Asia. India, the Indian Ocean and China's 'String of Pearls'." Indian Express, May 31

19. Mukherjee, Tuneer. 2020. "Sino-Indian Maritime Competition: Shadow Fighting in the Indian Ocean." South Asian Voices, June 7, retrieved:

https://southasianvoices.org/sino-indian-maritime-competition-shadow-fightingin-the-indian-ocean/

20. Nanda, P. 2002. "Strategic Significance of the Andamans." Bharat Rakshak Monitor 5/3, re-cited in P. Nanda, 'Strategic Significance of the Andamans', Bharat Rakshak Monitor 5/3, Issue: 3, retrieved: http://www.bharatrakshak.com/MONITOR/ISSUE5-3/nanda.html

21. Panda, A. 2020. "A Skirmish in Galwan Valley: India and China's Deadliest Clash in More Than 50 Years." The Diplomat, June 16, retrieved:

https://thediplomat.com/2020/06/a- skirmish-in-galwan-valley-india-and-chinasdeadliest-clash-in-more-than-50-years/

22. Parker, G. 1998. Past, Present and Future. London: Pinter Press

23. Paul, T. V. 2018. "How India Will React to the Rise of China: The Soft-Balancing Strategy Reconsidered." War on the Rocks, September 17, retrieved: https://warontherocks.com/2018/09/india-and-the- rise-of-china-soft-balancingstrategy-reconsidered/

24. Pillay, D. P. K. 2020."Cooperation, not Confrontation: Changing the Rules of the China Game." The Economic Times, June 17, retrieved, 2020 from 
https://economictimes.indiatimes.com/news/defence/cooperation-notconfrontation- changing-the-rules-of-the-china-game/articleshow/76356833.cms

25. Ratha, Keshab Chandra. 2014. "India-China Bilateral Relations: Confrontation and Reconciliation." Conference Paper, September 26, Odisha, India

26. Reyar, A. 2020. "India-China Standoff: Where is Galwan Valley and Why is it so Strategic?" Times Now, June 16, retrieved:

https://www.timesnownews.com/columns/article/india-china-standoff-where-isgalwan-valley-and-why-is-it-so-strategic/607317

27. Sharma, Buddhi Prasad 2019. "Belt and Road, Overview of Developing Countries like Nepal." China and the World: Ancient and Modern Silk Road, Vol. 2, No. 3, 1 33, DOI: 10.1142/S2591729319500160

28. Sharma, Buddhi Prasad and Khatri, Raunab Singh. 2019. "The Politics of Soft Power, Belt and Road Initiative as a Charm Influence in South Asia." China and the World: Ancient and Modern Silk Road, Vol. 2, No. 1, 1-29, Accessed September 27, 2020. doi: 10.1142/S2591729319500020

29. Scott, David. 2008. "The Great Power 'The Great Game' between India and China: 'The Logic of Geography." Geopolitics, 13:1-26, Accessed October 6, 2020.doi: 10.1080/14650040701783243

30. Sinha, Y. 2003. "The Emerging India- China Relationship and its Impact on India/South Asia." Indian Ministry of External Affair's Statement, Nov 22, retrieved: http://mea.gov.in/speech/2003/11/22ss01.htm

31. South China Morning Post. 1998. "Beijing No. 1 Threat Says India Official".

32. Spykman, N. 1944. The Geography of the Peace. New York: Harcourt, Brace and Company

33. The Hindu, 2020. "Indian Army Says 20 Soldiers Killed in Clash with Chinese Troops at Galwan Area." June 16, Accessed October 10, 2020, retrieved: https://www.thehindu.com/news/national/indian-army-says-20-soldiers-killed-inclash-with-chinese-troops-in-the-galwan-area/article31845662.ece

34. World Affairs. 2020. "India as a Tool to Contain China- Geopolitics Explained." June 13, retrieved: https://worldaffairs.blog/2020/06/13/india-as-a-tool-tocontain-china-geopolitics-explained/

35. Ye, Min. 2020. "Asia's Near Future? China's New Plans and Implications for East Asia and India." China-India Brief, November 27, retrieved:

36. https://lkyspp.nus.edu.sg/cag/publications/details/china-india-brief-172

37. Yu, Zeyuan. 2020. "China-India Border Clash: Will India's Misconceptions of China's Strength Lead to War." ThinkChina, June 18, retrieved: https://www.thinkchina.sg/china-india-border-clash-will-indias-misperceptionschinas-strength-lead-war

38. Zhang, Guihong. 2005. "US-China Strategic Partnership: Implications for China." International Studies, 42//3-4, p. 289 